\title{
DRYING KINETICS OF BANANAS BY NATURAL CONVECTION: INFLUENCE OF TEMPERATURE, SHAPE, BLANCHING AND CULTIVAR
}

\author{
Cinética de secagem de bananas por convecção natural: Influência da \\ temperatura, formato, branqueamento e cultivar
}

\author{
Soraia Vilela Borges ${ }^{1}$, Maurício C. Mancini², Jefferson Luiz Gomes Corrêa ${ }^{3}$, Julia Benedito Leite ${ }^{4}$
}

\begin{abstract}
The influence of variables as temperature, solid shape, temperature, branching and cultivar on drying of bananas were studied. Bananas from cv. Prata and D'água, on disk and cylindrical shape, blanched or not, were dehydrated in a tray dryer in natural convection at 40 and $70^{\circ} \mathrm{C}$. Drying behavior was analyzed by using a mathematical model. The exponential model showed good agreement to experimental data ( $\mathrm{r}^{2} 0.93$ - 0.99 and standard error: $\left.0.01-0.05\right)$. Temperature presented positive influence on drying rate in all the tested conditions. With respect to the sample shape, the disk shape carried out to significantly higher drying rates only for D'água cultivar without blanching. Blanching was significantly influent, with positive influence, on drying rate of banana cv. Prata at $40^{\circ} \mathrm{C}$. The influence of the cultivar did not present a defined tendency.
\end{abstract}

Index terms: Fruit, dehydration, pretreatment.

\section{RESUMO}

No presente trabalho, estudou-se a influência de variáveis como temperatura, formato do sólido, branqueamento e cultivar na secagem de bananas. Bananas cultivares Prata e D'água, nos formatos disco e cilindro, branqueadas ou não, foram desidratadas em secador de bandejas com convecção natural nas temperaturas de 40 e $70^{\circ} \mathrm{C}$. O comportamento da secagem foi analisado utilizandose modelagem matemática. O modelo exponencial mostrou bom ajuste aos resultados experimentais $\left(r^{2}: 0,93-0,99\right.$ e erro de estimativa padrão: $0,01-0,04)$. A temperatura apresentou influência positiva na taxa de secagem em todas as condições testadas. Com relação ao formato das amostras, o formato disco conduziu a taxas de secagem significativamente maiores somente para o cultivar D'água e sem branqueamento. $O$ branqueamento se mostrou significativamente influente, com influência positiva na taxa de secagem da banana Prata a $40^{\circ} \mathrm{C}$. A influência da cultivar não apresentou uma tendência definida.

Termos para indexação: Fruta, desidratação, pré-tratamento.

(Received in august 18, 2009 and approved in september 14, 2010)

\section{INTRODUCTION}

Banana (Musa ssp.) is a fruit of great economical importance for Brazil (Pereira et al., 2009). The annual Brazilian production of banana is about seven million tons (Instituto Brasileiro de Geografia e Estatística - IBGE, 2007). Besides, there is a great annual loss (Silva et al., 2003). Among the useful processes used to preserve fruits are minimal processing (Melo et al., 2009; Vilas-Boas et al., 2009; Pinheiro et al., 2010), refrigeration (Damiani et al., 2009; Fernandes et al., 2010) and dehydration or drying (Leite et al., 2007; Borges et al., 2008; Corrêa et al., 2008, 2010; Aquino et al., 2009). Drying of banana is an interesting alternative to reduce losses (Grabert et al., 2001) and to improve food commercial value (Bittencourt et al., 2004), which makes this process, a potential agrobusiness.

Drying of bananas has been studied in several different ways as, for example, solar drying (Smitabhindua et al., 2008), drying using vacuum (Swasdisevi et al., 2009), foam mat drying (Thuwapanichayanan et al., 2009), spray drying (Evelin et al., 2009), among others. Dried banana is a food stock in ripe (Leite et al., 2007; Jalili et al., 2008) or unripe maturation state (Pacheco-Delahaye et al., 2008; Borges et al., 2010). The dehydration of banana results also in physical modifications as color change (Prachayawarakorn et al., 2008), shrinkage and porosity (Katekawa \& Silva, 2007; Hofsetz et al., 2008; Yan et al., 2008) and texture (Kotwaliwale et al., 2007; Prachayawarakorn et al., 2008).

Based on these facts, it is important to know the influence of dehydration process variables to guarantee the obtainment of dried fruits with quality. Such parameters are appropriate cultivar, pre-treatments, and drying conditions (Queiroz \& Nebra, 2001; Demirel \& Turhan, 2003; Mota, 2005; Fernandes et al., 2006; Leite et al., 2007; Nguyen \& Price, 2007; Jalili et al., 2008).

\footnotetext{
1Universidade Federal de Lavras/UFLA - Departamento de Ciência dos Alimentos - Cx. P. 3037 - 37200-000 - Lavras, MG - sborges@ufla.br 2Universidade Federal Rural do Rio de Janeiro/UFRRJ - Departamento de Engenharia Química - Seropédica, RJ

3Universidade Federal de Lavras/UFLA - Lavras, MG

${ }^{4}$ Seropédica, RJ
} 
The goal of this work was the study of the influence of variables as temperature, fruit shape, blanching and cultivar in drying kinetics of bananas cv. Prata and D'água, in a natural convection tray dryer. A mathematical model was applied to fit the drying kinetics.

\section{MATERIAL AND METHODS}

\section{Raw material}

The bananas were purchased at a local market, in uniform ripening grade, appropriated for drying (yellow with some black points, according to Travaglini et al. (1993)), with average moisture content of $3.5 \mathrm{~g} / \mathrm{g}$ (d.b.) for cv. Prata and $4.4 \mathrm{~g} / \mathrm{g}$ (d.b.) for cv. D'água.

\section{Material preparation}

The fruits were washed with tap water and manually peeled. The bananas were cut in disk shape $(0.5 \mathrm{~cm}$ of thickness with the fruit average diameter of about $3.5 \pm 0.3 \mathrm{~cm}$ ) and cylindrical shape $(10 \mathrm{~cm}$ of length with the fruit average diameter of about $3.5 \pm 0.3 \mathrm{~cm})$.

\section{Blanching}

The experiments with blanching were performed by immersing the samples in boiling water for 1 minute and after in a cold bath $\left(0^{\circ} \mathrm{C}\right)$ for 1 minute.

\section{Drying}

Natural convection drying was performed in a tray dryer at 40 and at $70^{\circ} \mathrm{C}$ in time intervals $(1,2,3,4,5,6,7,8$ and 24 hours) to determine the drying kinetics and moisture content. The experiment was done in triplicate. The moisture content analysis was obtained according to Association of Official Analytical Chemists - AOAC (2002).

\section{Mathematical model}

Kinetics drying curves were adjusted with and exponential model that relates the ratio moisture content / initial moisture content with drying time. Such model was also used by Alcina et al. (1997) and Cano-Chauca et al. (2004).

This model considers that:

$$
\begin{aligned}
& \frac{d Y_{s}^{*}}{d t}=-k Y_{s}^{*} \\
& \text { with } \\
& Y_{s}^{*}=\frac{Y_{s t}}{Y_{s 0}}
\end{aligned}
$$

where $\mathrm{Y}_{\mathrm{st}}$ is the solid moisture content at a given time, $\mathrm{Y}_{\mathrm{s} 0}$, solid moisture content before drying and $\mathrm{Y}_{\mathrm{s}}^{*}$ is an non dimensional solid moisture (ratio).

The initial condition is:

$$
Y_{s 0}^{*}=1
$$

The term $\mathrm{Y}_{\mathrm{s}}$ is then given by:

$Y_{s}^{*}=k_{0} \exp \left(-k_{1} t\right)$

where $\mathrm{k}_{0}$ corresponds to the initial condition and should be around the unity.

The results were adjusted by equation (3) and evaluated with respect to the correlation coeficient $\left(\mathrm{r}^{2}\right)$ and standard error (SE), according to Pimentel-Gomes (1999).

\section{RESULTS AND DISCUSSION}

\section{Influence of the temperature}

The influence of the temperature can be evaluated by the inspection of Figures 1 to 6 . In all these figures, one can see that drying rate increases in a proportional way to the drying temperature. This can be explained with respect to the diffusion coefficient of water that increases with temperature and is decisive in natural convection (Wang $\&$ Chen, 1999). The influence of the temperature is more relevant in the first period of drying, called the period of constant rate. In this period, gradients of water are higher and also the diffusivity. Such behavior is largely published in drying works (Kouris \& Vagenas, 1991; Tsami \& Katsioti, 2000; Queiroz \& Nebra, 2001; Krokida et al., 2003; Sacilik, 2007; Silva et al., 2008; Simioni et al., 2008).This can be corroborate by the parameter of experimental adjustment, $\mathrm{k}_{1}$ (Table 1), which corresponds to a rate between $\ln \left(\mathrm{Y}_{\mathrm{st}} / \mathrm{Y}_{0}\right)$ and $t$ and is presented in equation 3 .

\section{Influence of the shape}

Table 1 shows that the difference with respect to the shape is more evident at $70^{\circ} \mathrm{C}$. Except for banana 'Prata' without blanching, the disk shape carried out to a higher $\mathrm{k}_{1}$. However, if the average standard error of the experimental values of $\mathrm{Y}$ is considered as $10 \%$, the disk shape presented a significant higher drying rate for banana cv. D'água at $70^{\circ} \mathrm{C}$ (Figure 2).

\section{Influence of blanching}

Blanching presented a significant and positive influence only for cultivar Prata at $40^{\circ} \mathrm{C}$ in both shapes 
(Figures 3 to 6 and Table 1). This trend was also observed in similar works with other fruits (Dandamrongrak et al., 2002; Arévalo-Pinedo \& Murr, 2005). Blanching increases drying rate due to the physical changes of the tissue and destruction of cellular membrane promoted by the heating (Mazza, 1983). On the other hand, at $70^{\circ} \mathrm{C}$, blanching was not influent. This can be related to the gelatinization of banana starch, which occurs at $65^{\circ} \mathrm{C}$ (Demirel \& Turham, 2003). Demirel \&
Turham (2003) also obtained similar results in drying tests of slices of banana cv. Dwarf Cavendish and Gros Michel at $70^{\circ} \mathrm{C}$.

\section{Influence of the cultivar}

Table 1 shows that cultivar did not present a clear tendency. The inference of this table shows that with blanching, cv. Prata presented higher $\mathrm{k}_{1}$ values for both shapes and both temperatures. Otherwise, without

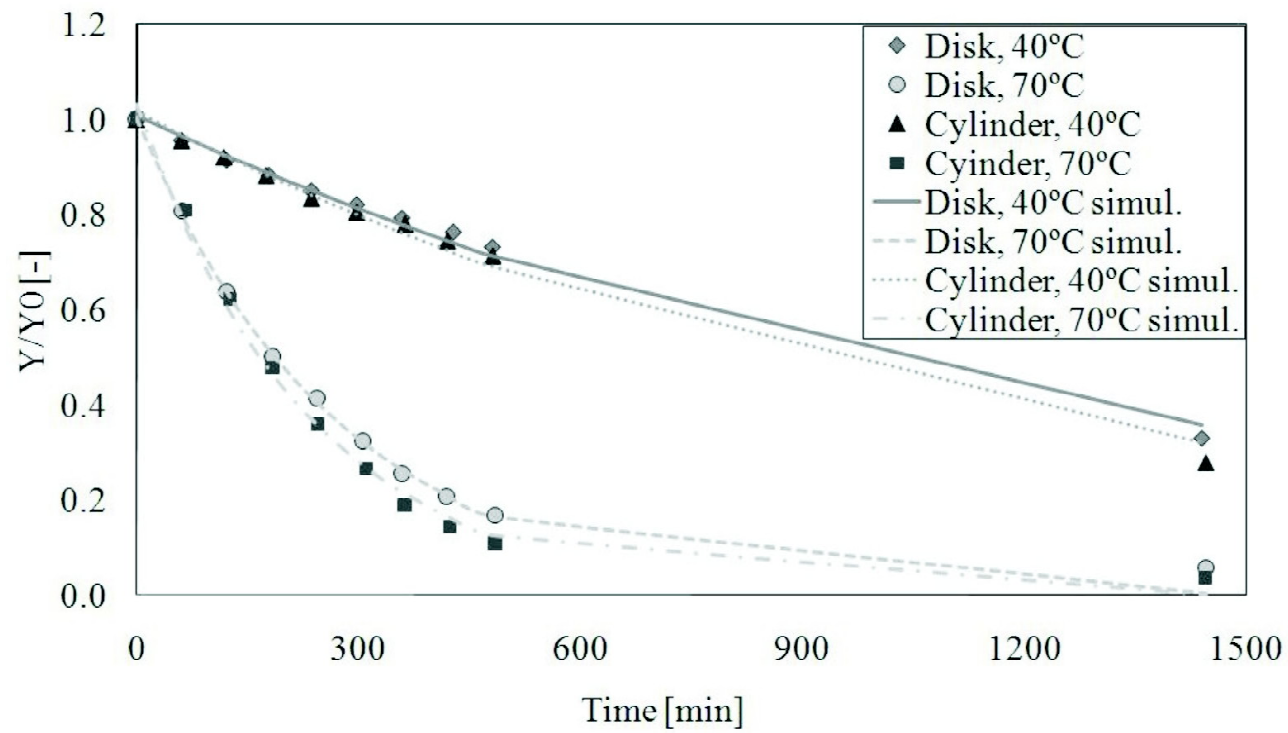

Figure 1 - Drying kinetics for banana cv. Prata at disk and cylinder shape, without blanching.

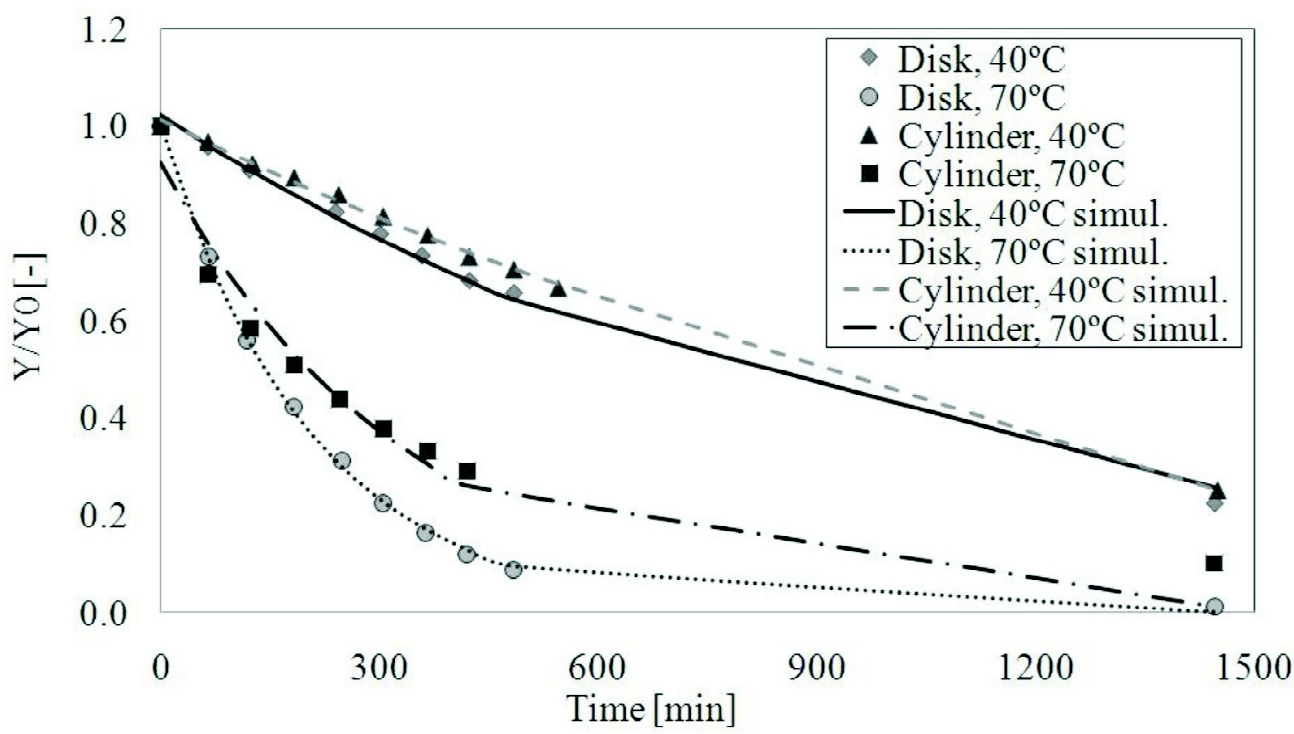

Figure 2 - Drying kinetics for banana cv. D’água at disk and cylinder shape, without blanching. 
blanching, disk shape carried out to higher $\mathrm{k}_{1}$ for cv. D'água and cylinder shape presented higher $\mathrm{k}_{1}$ for $\mathrm{cv}$. Prata, for both studied temperatures.

\section{Mathematical model}

Table 1 presents the parameters obtained with equation 3 and the adjustment data $r^{2}$ and SE. It was verified that the parameter $\mathrm{k}_{0}$ was always nearby the unity, what is in accordance with the physical meaning of initial moisture content. It can be observed (Table 1 and Figures 1 to 6 ) that the mathematical model used here gave a satisfactory agreement $\left(\mathrm{r}^{2} \geq 0.937\right.$ and $\left.\mathrm{SE} \leq 0.048\right)$. The non dimensional moisture content, $\mathrm{Y}$ is in the range $0.0<\mathrm{Y}<1.0$ and the highest estimative standard error of (SE) is 0.048 . With this in mind, it can be said that SE is much appropriated. Moreover, a correlation coefficient $\left(r^{2}\right)$ higher our equal to 0.937 is a pertinent parameter of adjustment.

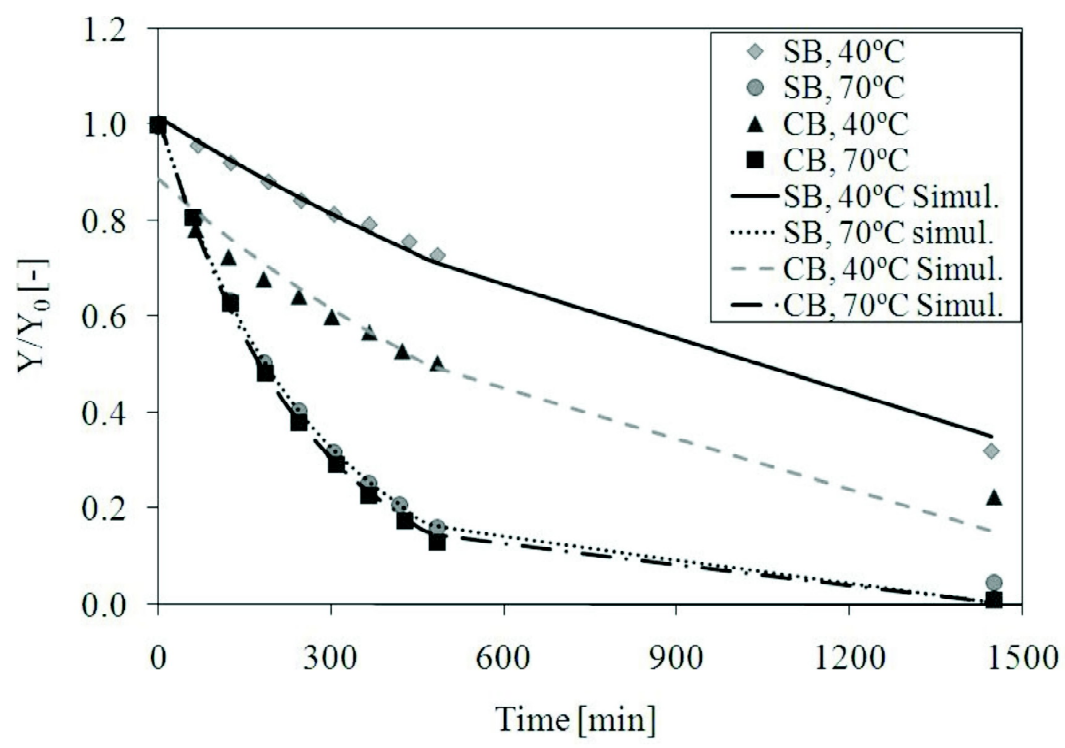

Figure 3 - Drying kinetics for banana cv. Prata, disk shape (CB- with blanching; SB- without blanching).

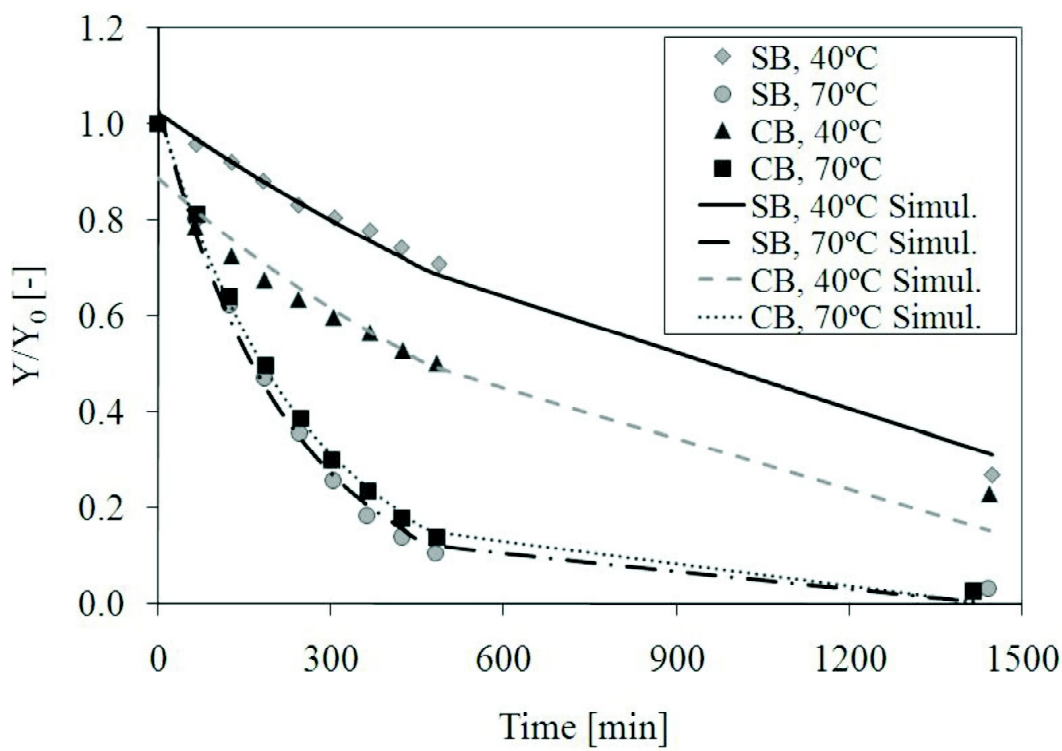

Figure 4 - Drying kinetics for banana cv. Prata, cylinder shape (CB- with blanching; SB- without blanching). 
The curves obtained with the model were explored to estimate the critical moisture content. The values for each condition are presented in Table 1 . It can be seen that critical moisture decrease with increasing.temperature.
Temperature raises kinetic energy of water vapor and, as a consequence, water vapor diffusivity increasing. Such situation causes drying rate increase and critical moisture reduction.

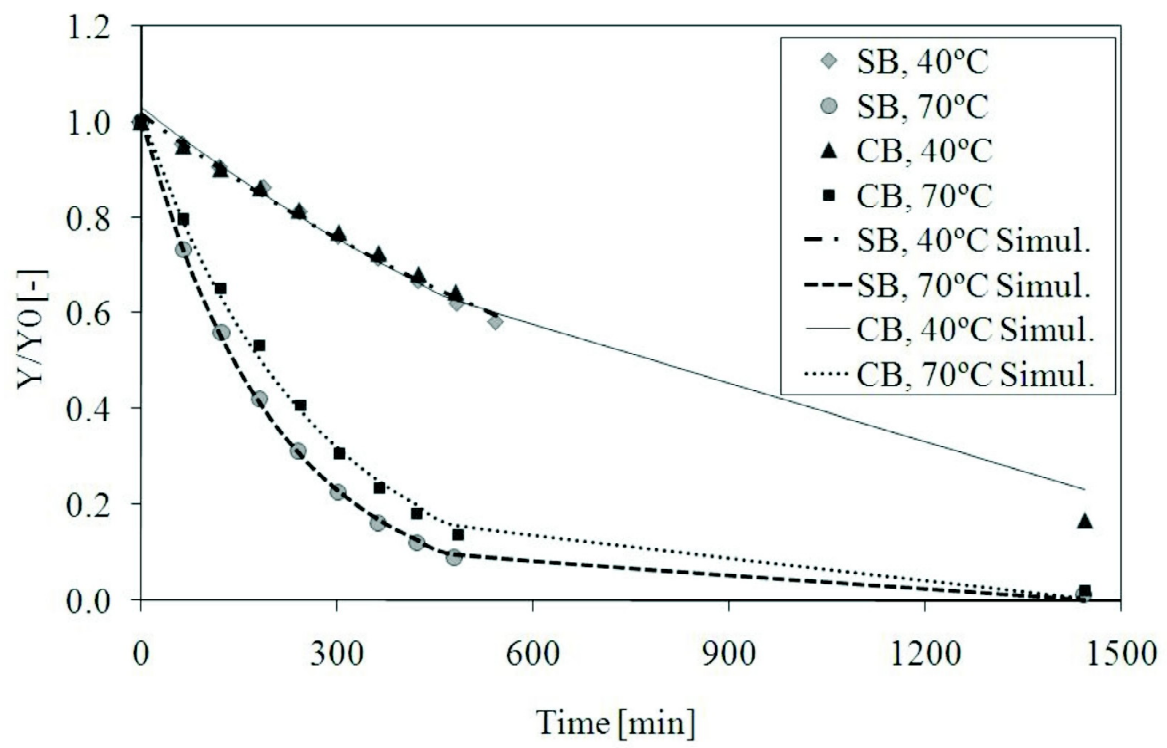

Figure 5 - Drying kinetics for banana cv. D’água, disk shape (CB- with blanching; SB- without blanching).

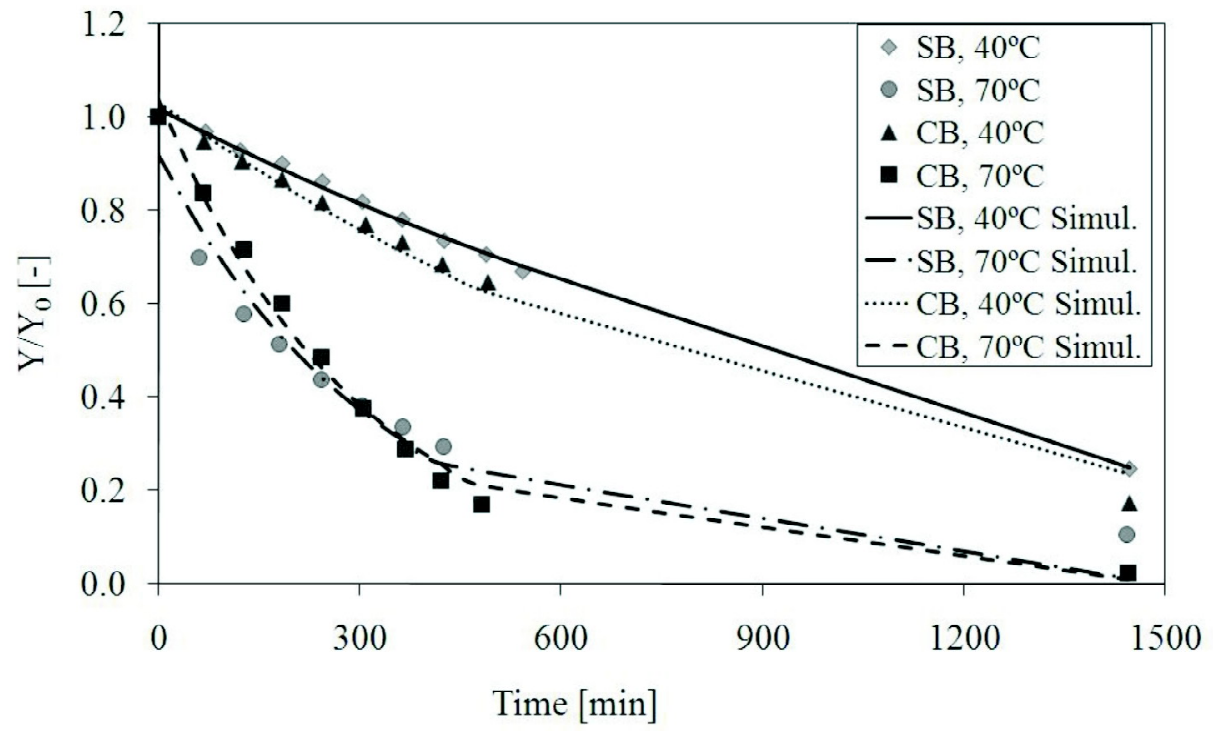

Figure 6 - Drying kinetics for banana cv. D'água, cylinder shape (CB- with blanching; SB- without blanching). 
Table 1 - Parameters of Equation 3, adjustment data and critical moisture for drying kinetics of banana cv. Prata and D’água in disk and cylinder shape, with and without blanching.

\begin{tabular}{|c|c|c|c|c|c|}
\hline Shape, Temperature & $\mathrm{k}_{0}$ & $\mathrm{k}_{1} \times 10^{3}$ & $\mathrm{r}^{2}$ & SE & $\mathrm{Mc}[\mathrm{g} / \mathrm{g}]$ \\
\hline \multicolumn{6}{|c|}{ Banana cv. Prata without blanching } \\
\hline Disk, $40^{\circ} \mathrm{C}$ & 1.009 & 0.719 & 0.993 & 0.014 & 0.55 \\
\hline Disk, $70^{\circ} \mathrm{C}$ & 1.004 & 3.714 & 0.996 & 0.018 & 0.13 \\
\hline Cylinder, $40^{\circ} \mathrm{C}$ & 1.017 & 0.806 & 0.991 & 0.018 & 0.54 \\
\hline Cylinder, $70^{\circ} \mathrm{C}$ & 1.032 & 4.333 & 0.994 & 0.023 & 0.10 \\
\hline \multicolumn{6}{|c|}{ Banana cv. Prata with blanching } \\
\hline Disk, $40^{\circ} \mathrm{C}$ & 0.889 & 1.211 & 0.938 & 0.048 & 0.39 \\
\hline Disk, $70^{\circ} \mathrm{C}$ & 1.016 & 4.014 & 0.999 & 0.010 & 0.14 \\
\hline Cylinder, $40^{\circ} \mathrm{C}$ & 0.890 & 1.221 & 0.937 & 0.048 & 0.38 \\
\hline Cylinder, $70^{\circ} \mathrm{C}$ & 1.026 & 3.964 & 0.997 & 0.017 & 0.11 \\
\hline \multicolumn{6}{|c|}{ Banana cv. D'água without blanching } \\
\hline Disk, $40^{\circ} \mathrm{C}$ & 1.023 & 0.960 & 0.995 & 0.015 & 0.55 \\
\hline Disk, $70^{\circ} \mathrm{C}$ & 1.002 & 4.852 & 0.999 & 0.008 & 0.10 \\
\hline Cylinder, $40^{\circ} \mathrm{C}$ & 1.014 & 0.745 & 0.994 & 0.008 & 0.57 \\
\hline Cylinder, $70^{\circ} \mathrm{C}$ & 0.923 & 3.024 & 0.956 & 0.051 & 0.21 \\
\hline \multicolumn{6}{|c|}{ Banana cv. D'água with blanching } \\
\hline Disk $40^{\circ} \mathrm{C}$ & 1.031 & 1.032 & 0.987 & 0.025 & 0.51 \\
\hline Disk $70^{\circ} \mathrm{C}$ & 1.018 & 3.854 & 0.997 & 0.017 & 0.12 \\
\hline Cylinder $40^{\circ} \mathrm{C}$ & 1.032 & 1.021 & 0.986 & 0.026 & 0.51 \\
\hline Cylinder $70^{\circ} \mathrm{C}$ & 1.038 & 3.322 & 0.991 & 0.028 & 0.20 \\
\hline
\end{tabular}

where $\mathrm{K}_{0}$ and $\mathrm{K}_{1}$ are parameters of the equation $3, \mathrm{Y}_{\mathrm{S}}^{*}=\mathrm{k}_{0} \exp \left(-\mathrm{k}_{1} \mathrm{t}\right), \mathrm{r}^{2}$ and $\mathrm{SE}$ are correlation coefficient and estimative standard error and $\mathrm{M}_{\mathrm{C}}$, the critical moisture content obtained from the simulated data (w.b.).

\section{CONCLUSIONS}

In experiments of drying kinetics of bananas cultivar D'água and Prata in heat natural convection condition, at 40 and $70^{\circ} \mathrm{C}$, the influence of temperature, shape, blanching and cultivar were as follows:

Temperature presented a positive influence on the drying rate for both cultivar and both shape.

The Disk shape presented significant higher drying rate with respect to the cylindrical shape only for banana cv. D'água at $70^{\circ} \mathrm{C}$.

Blanching presented a significant influence only for cv. Prata at $40^{\circ} \mathrm{C}$, in both shapes.

There was not a well defined trend on the curves of drying kinetics with respect to the cultivar.

The exponential mathematical model resulted in good adjustments and helped in the phenomena analysis.

\section{REFERENCES}

ALCINA, O.L.S.; SILVA, O.S.; BRASILEIRO, M.N. Drying kinetics of West Indian Cherry. In: INTERAMERICAN DRYINGCONFERENCE, 1., 1997, Itu. Proceedings... Itu, 1997. p.434-440.

AQUINO, L.P.; FERRUA, F.Q.; BORGES, S.V.; ANTONIASSI, R.; CORREA, J.L.G.; CIRILO, M.A. Influência da secagem de pequi (Caryocar brasiliense Camb.) na qualidade do óleo extraído. Ciência e

Tecnologia de Alimentos, Campinas, v.29, p.354-357, 2009.

ARÉVALO-PINEDO, A.; MURR, F.E.X. Influência da pressão, temperatura e pré-tratamentos na secagem a vácuo de cenoura e abóbora. Ciência e Tecnologia de Alimentos, Campinas, v.2, n.4, p.636-642, 2005. 
ASSOCIATION OF OFFICIALANALYTICAL CHEMISTS. Official methods of analysis. 17.ed. Maryland, 2002.

BITTENCOURT, J.; QUEIROZ, M.R.; NEBRA, S.A. Avaliação econômica da elaboração de banana-passa proveniente do cultivo orgânico e convencional. Engenharia Agrícola, Jaboticabal, v.24, n.2, p.473-483, 2004.

BORGES, A.M.; PEREIRA, J.; SILVA JÚNIOR, A.; LUCENA, E.M.P.; SALES, J.C. Estabilidade da pré mistura de bolo elaborada com $60 \%$ de farinha de banana verde. Ciência e Agrotecnologia, Lavras, v.34, n.1, p.173181, 2010.

BORGES, S.V.; MANCINI, M.C.; CORRÊA, J.L.G.; NASCIMENTO, D.A. Secagem de fatias de abóboras (Curcubit moschata, L.) por convecção natural e forçada. Ciência e Tecnologia de Alimentos, Campinas, v.28, p.245-251, 2008.

CANO-CHAUCA, M.; RAMOS, A.M.; STRINGHETA, P.C.; PEREIRA, J.A.M. Drying curves and water evaluation of dryed banana. In: INTERNATIONAL DRYING SYMPOSIUM, 14., 2004, São Paulo.

Proceedings... São Paulo, 2004. p.2013-2020.

CORREA, J.L.G.; CACCIATORE, F.A.; SILVA, Z.A.; ARAKAKI, T. Desidratação osmótica de acerola (Malpighia emarginata D.C) cinética de transferência de massa. Revista Ciência Agronômica, Fortaleza, v.39, p.403-409, 2008.

CORRÊA, J.L.G.; PEREIRA, L.M.; VIEIRA, GS.; HUBINGER, M.D. Mass transfer kinetics of pulsed vacuum osmotic dehydration of guavas. Journal of Food Engineering, Amsterdam, v.96, p.498-504, 2010.

DAMIANI, C.; VILAS-BOAS, E.V.B.; PINTO, D.M.; RODRIGUES, L.J. Influence of different temperatures in maintenance of quality of fresh-cut Pequi. Ciência e Agrotecnologia, Lavras, v.32, n.1, p.203-212, 2010.

DANDAMRONGRAK, R.; YOUNG, G; MASON, R. Evaluation of various pre-treatments for the dehydration of banana and selection of suitable drying models. Journal of Food Engineering, Amsterdam, v.55, p.139146, 2002.
DEMIREL, D.; TURHAN, M. Air-drying behavior of Dwarf Cavendish and Gros Michel banana slices. Journal of Food Engineering, Amsterdam, v.59, n.1, p.111, 2003.

EVELIN, M.A.; JACOB, J.P.; VIJAYANAND, D. Packaging and storage studies on spray dried ripe banana powder under ambient conditions. Journal of Food Science and Technology, Mysore, v.44, n.1, p.16-21, 2007.

FERNANDES, F.A.N.; RODRIGUES, S.; GASPARETO, O.C.P.; OLIVEIRA, E.L. Optimization of osmotic dehydration of bananas followed by air-drying. Journal of Food Engineering, Amsterdam, v.77, n.1, p.188-193, 2006.

FERNANDES, T.N.; RESENDE, J.V.; CRUVINEL, R.S.R.; RENO, M.J. Relação entre o comportamento reológico e a dinâmica do congelamento e descongelamento de polpa de morango adicionada de sacarose e pectina. Ciência e Tecnologia de Alimentos, Campinas, v.30, p.188-204, 2010.

GRABERT, M.; FÁVARO, S.P.; MUSIS, C.R. Avaliação da qualidade sensorial de banana passa obtida em secador de frutos por convecção natural. Revista Brasileira de Armazenamento, Viçosa, v.26, p.10-15, 2001.

HOFSETZ, K.; LOPES, C.C.; HUBINGER, M.D.; MAYOR, L.; SERENO, A.M. Changes in the physical properties of bananas on applying HTST pulse during air-drying. Journal of Food Engineering, Amsterdam, v.83, p.531-540, 2007.

INSTITUTO BRASILEIRO DE GEOGRAFIA E ESTATÍSTICA. Previsão de safra-Brasil 2006-2007. Disponível em: <www:sidra.ibge.gov.br>. Acesso em: 4 dez. 2007.

JALILI, V.R.R.; NARAIN, N.; SILVA, G.F. Effect of osmotic predehydration on drying characteristics of banana fruits. Ciência e Tecnologia de Alimentos, Campinas, v.28, n.2, p.269-273, 2008.

KATEKAWA, M.E.; SILVA, M.A. Drying rates in shrinkage medium: case study of banana. Brazilian Journal of Chemical Engineering, Campinas, v.24, p.561-569, 2007. 
KOTWALIWALE, N.; BAKANE, P.; VERMA, A. Changes in textural and optical properties of oyster mushroom during hot air drying. Journal of Food Engineering, Amsterdam, v.78, p.1207-1211, 2007.

KOURIS, D.M.; VAGENAS, G.K. Drying kinetics of apricots. Drying Technology, New York, v.9, n.3, p.735$752,1991$.

KROKIDA, M.K.; KARATHANOS, V.T.; MAROULIS, Z.B.; MARINOS-KOURIS, D. Drying kinetics of some vegetables. Journal of Food Engineering, Amsterdam, v.59, n.4, p.391-403, 2003.

LEITE, J.B.; MANCINI, M.C.; BORGES, S.V. Effect of drying temperature on the quality of dried bananas $\mathrm{cv}$. prata and d'água. Lebensmittel Wissenschaft und Technologie, London, v.40, n.2, p.319-323, 2007.

MAZZA, G. Dehydration of carrots: effects of pré-drying treatments on moisture transport and product quality. Food Technology, Chicago, v.18, p.113-123, 1983.

MELO, A.A.M.; VILAS-BOAS, E.V.B.; JUSTO, C.F. Use of chemical additives for postharvest concervation of fresh cut "apple" banana. Ciência Agronômica, Lavras, v.33, p.228-236, 2009.

MOTA, R.V. Avaliação da qualidade de banana passa elaborada a partir de 6 cultivares. Ciência e Tecnologia de Alimentos, Campinas, v.25, n.3, p.560-563, 2005.

NGUYEN, M.H.; PRICE, W.E. Air-drying of banana: influence of experimental parameters, thickness, banana maturity and harvesting season. Journal of Food Engineering, Amsterdam, v.79, p.200-207, 2007.

PACHECO-DELAHAYE, E.; MALDONADO, R.; PEREZ, E.; SCHROEDER, M. Production and characterization of unripe plantain (Musa paradisiaca L.) flours.

Interciencia, Caracas, v.33, p.290-296, 2008.

PEREIRA, L.V.; ANDRADE, J.C.; FRÁGUAS, J.C.; ABRAHÃO, E.; ALVARENGA, A.A. Analysis of banana trade in Lavras, Minas Gerais. Ciência Agronômica, Lavras, v.33, p.863-869, 2009.

PIMENTEL-GOMES, F. Curso de estatística experimental. São Paulo: Nobel, 1999.
PINHEIRO, A.C.M.; VILAS-BOAS, E.V.B.; BOLINI, H.M.A. Prolongamento da vida pós-colheita de bananas-maçã submetidas ao 1-metilciclopropeno (1MCP): qualidade sensorial e física. Ciência e Tecnologia de Alimentos, Campinas, v.30, p.132-137, 2010.

PRACHAYAWARAKORN, S.; TIA, W.; PLYTO, N.; SOPONRONNARIT, S. Drying kinetics and quality attributes of low-fat banana slices dried at high temperature. Journal of Food Engineering, Amsterdam, v.85, p.509-517, 2008.

QUEIROZ, M.R.; NEBRA, S.A. Theoretical and experimental analysis of the drying kinetics of bananas. Journal of Food Engineering, Amsterdam, v.47, p.127132, 2001.

SACILIK, K. Effect of drying methods on thin-layer drying characteristics of hull-less seed pumpkin (Curcubita pepo L.). Journal of Food Engineering, Amsterdam, v.79, n.1, p.23-30, 2007.

SILVA, A.S.; GURJÃO, K.C.O.; ALMEIDA, F.A.C.; BRUNO, R.L.A.; PEREIRA, W.E. Dehydration of tamarind pulp through the foam-mat drying method. Ciência e Agrotecnologia, Lavras, v.32, n.6, p.1899-1905, nov./dez. 2008.

SILVA, C.S.; PEROSE, J.M.Y.; RUA, P.S.;ABREU, C.L.M. de; PÂNTANO, S.C.; VIEIRA, C.R.Y.I.; BRIZOLA, R.M.O. Economic avaliation of the banana's losses in retatil trade: a case study. Revista Brasileira de Fruticultura, Jaboticabal, v.25, n.2, p.229-234, ago. 2003.

SIMIONI, D.; OLIVEIRA, M.; PAGNUSSATT, F.A.; DEUNER, C.C.; GUTKOSKI, L.C.; ELIAS, M.C. Operational parameters in intermittent drying of white oat grains UPFA 20 Teixeirinha cultivar. Ciência e Agrotecnologia, Lavras, v.32, n.2, p.497-502, mar./abr. 2008.

SMITABHINDUA, R.; JANJAIB, S.; CHANKONGC, V. Optimization of a solar-assisted drying system for drying bananas. Renewable Energy, v.33, p.1523-1531, 2008.

SWASDISEVI, T.; DEVAHASTIN, S.; SA-ADCHOM, P.; SOPONRONNARIT, S. Mathematical modeling of combined far-infrared and vacuum drying banana slice. Journal of Food Engineering, Amsterdam, v.92, p.100106, 2009. 
THUWAPANICHAYANAN, R.; PRACHAYAWARAKORN, S.; SOPONRONNARIT, S. Drying characteristics and quality of banana foam mat. Journal of Food Engineering,

Amsterdam, v.86, p.573-583, 2008.

TRAVAGLINI, D.A.; BLEINROTH, E.W.; LEITÃO, M.F.F. Banana-passa: princípios de secagem. Campinas: ITAL, 1993. (Manual técnico, 12).

TSAMI, E.; KATSIOTI, M. Drying kinetics for some fruits:predicting of porosity and color during dehydratation. Drying Technology, New York, v.18, n.7, p.1559-1581, 2000.
VILAS-BOAS, E.V.B.; REIS, C.M.F;; MELO,A.A.M. Use of chemical mixtures for firmness maintenance of freshcut 'Silver' banana. Ciência Agronômica, Lavras, v.33, p.237-244, 2009.

WANG, Z.H.; CHEN, G. Heat and mass transfer during low intensity convection drying. Chemical Engineering Science, Amsterdam, v.54, n.17, p.3899-3908, Sept. 1999.

YAN, Z.; SOUSA-GALLAGHER, M.J.; OLIVEIRA,

F.A.R. Shrinkage and porosity of banana, pineapple and mango slices during air-drying. Journal of Food Engineering, Amsterdam, v.84, p.430-440, 2008. 